\title{
Paraganglioma of the vagina: a case report and review of the literature
}

This article was published in the following Dove Press journal:

OncoTargets and Therapy

10 June 2014

Number of times this article has been viewed

\author{
Tao Cai' \\ Yucong $\mathrm{Li}^{2}$ \\ Qingming Jiang ${ }^{3}$ \\ Dong Wang ${ }^{2}$ \\ Yu Huang ${ }^{2}$ \\ 'Department of Dermatology, The \\ First Affiliated Hospital of Chongqing \\ Medical University, ${ }^{2}$ Department of \\ Gynecologic Oncology, ${ }^{3}$ Department \\ of Pathology, Chongqing Cancer \\ Research Institute, Chongqing, \\ People's Republic of China
}

Correspondence: Yu Huang Department of Gynecologic Oncology, Chongqing Cancer Research Institute, 18I Hanyu Road, Shapingba, Chongqing 400030, People's Republic of China $\mathrm{Tel} / \mathrm{Fax}+862365075621$

Email amy_huang310@I63.com
Abstract: Vaginal paraganglioma is a rare and unusual tumor occurring in the vaginal wall. It is a solitary primary paraganglioma, especially in atypical sites. Herein, we report an unusual case of a 17-year-old woman who had not experienced vomiting, or hypertension. She was found to have an immobile solid mass in the right side of her vaginal wall. Positron emission tomography/ computed tomography scans revealed a well-defined solid ovoid mass adjacent to the bladder and pelvic floor. Tumor markers were within the normal range. A transient blood pressure increase occurred during the biopsy. After oral administration of antihypertensive drugs, surgery was performed to completely remove the mass. Histopathological examination indicated that it was a paraganglioma of the vagina. Repeat computed tomography examination did not reveal any local recurrence or distant metastasis during the 12-month follow-up period.

Keywords: vaginal paraganglioma, neuroendocrine tumor, clinical features, treatment

\section{Introduction}

Derived from neural crest cells, paraganglioma is formed by chromaffin or nonchromaffin neural epithelioid cells, which are related to sympathetic or parasympathetic nerves. ${ }^{1}$ Until now, there has been no uniform standard for its phase division and treatment. ${ }^{2}$ Paragangliomas are mostly distributed in paraganglion-gathering areas, such as the adrenal glands, neck, mediastinum, or retroperitoneum, ${ }^{3-5}$ but rarely occur in the vaginal wall. This report will analyze one case of a young woman who suffered from vaginal paraganglioma, together with a review of other relevant literature.

\section{Case report}

A 17-year-old woman with no history of marriage or pregnancy was hospitalized because of irregular vaginal bleeding over 5 months. She had no history of genetic disease, coagulation dysfunction, or liver cirrhosis, but had asthma. Physical examination revealed a blood pressure of $140 / 100 \mathrm{mmHg}$, a pulse rate of 95/minute, and no superficial lymph nodes could be palpated. Since the patient had had no sex, abdomen ultrasound was used instead of vaginal ultrasound. This showed that her uterus appeared normal in its dimensions, shape, and position. Both ovaries seemed normal for site, dimension, and echo structure. There was no free fluid in the Douglas pouch, while her pelvic computed tomography $(\mathrm{CT})$ showed a $40 \times 32 \mathrm{~mm}$ regular-margin hyperdense abnormal signal in the right vagina wall adjacent to the bladder. The results of positron emission tomography (PET)/CT were as follows: mass of soft-tissue density in the right vaginal wall and unusual hypermetabolism of fluorodeoxyglucose (FDG) matched with the tumor appearance; nodular soft-tissue density shadow in the pelvic 
cavity and hypermetabolism of FDG may have indicated the same lesion in the right vaginal wall. During biopsy of the vaginal tumor under intravenous anesthesia, her blood pressure suddenly rose to $160 / 100 \mathrm{mmHg}$, and then came back to $130 / 90 \mathrm{mmHg}$ after examination. The pathological diagnosis was vaginal paraganglioma.

After oral administration of sustained-release metoprolol and nifedipine tablets for 1 week, the woman had vaginal tumorectomy and reconstruction performed, and she had smooth blood pressure throughout the operation. The tumor mass was gray-white and taupe, with a size of $35 \times 30 \times 25 \mathrm{~mm}$ (Figure 1). Microscopically, polygon-like oncocytes were spread in nest or cluster forms. Abundant acidophilic granulates within the cytoplasm and round or oval karyons could be clearly identified. The tumor cells were clustered in small nests or irregular trabecular structures demarcated by delicate fibrous stroma and capillaries in the Zellballen pattern. In the tumor stroma, blood sinus, blood capillary, and little fibrous tissue could be found (Figure 2). Synaptophysin, chromogranin A, protein S-100, neuron-specific enolase, cell proliferation-associated antigen Ki67, and vimentin were all positive, while smooth-muscle actin, human melanomaassociated antigen (HMB-45), and cytokeratin were negative in immunohistochemistry assay (Figure 3).

\section{Discussion}

Paraganglioma is a rare soft-tissue neuroendocrine tumor, and can be classified as pheochromocytoma and extra-adrenal paraganglioma depending on its pathogenic site. The latter is closely related to tumors in the extra-adrenal sympathetic and parasympathetic paraganglioma, and named after the anatomic site as well as its functional activity. ${ }^{6}$ Paragangliomas have rarely been reported in the female genital tract, including

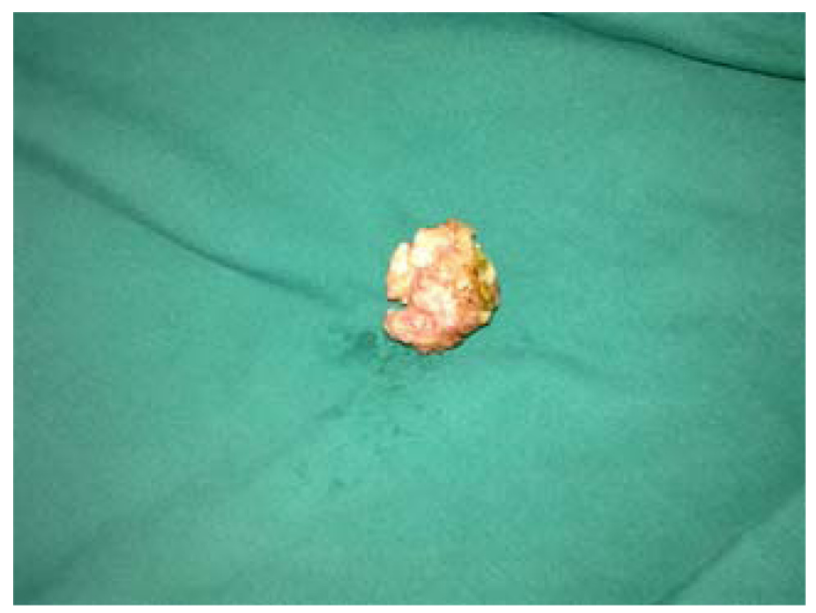

Figure I Surgical specimen of paraganglioma of vagina.

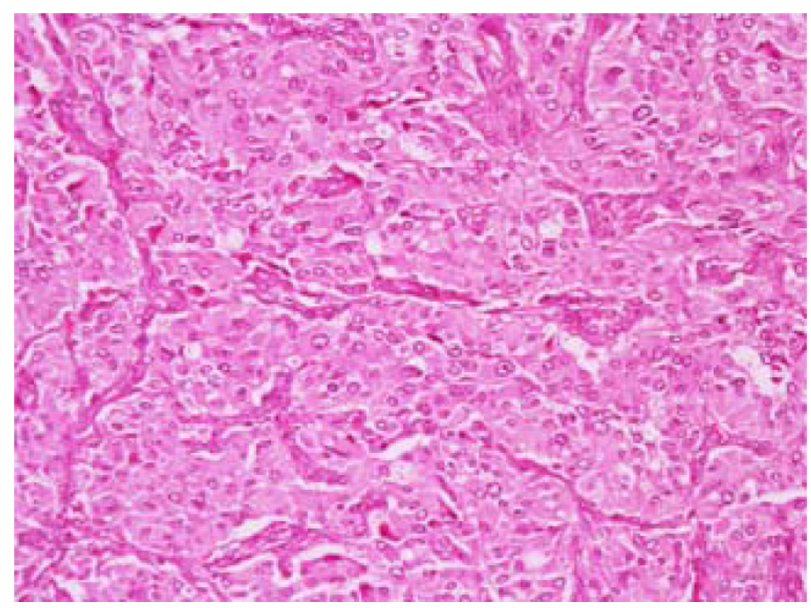

Figure 2 Vaginal tumor cells.

Note: Vaginal tumor cells showed nested aggregation and microscopically small nests composed of neoplastic cells having abundant cytoplasms demarcated by delicate fibrous stroma and capillaries in the Zellballen pattern (hematoxylin and eosin staining, 100x).

in the ovary, broad ligament, uterus, and vulva. ${ }^{7-14}$ To the best of our knowledge, only five cases of vaginal paraganglioma have been reported since 1998, with a median age of 31.3 years if including our case together. ${ }^{15-19}$

Furthermore, paragangliomas can be divided into functional and nonfunctional types according to their ability for synthesis, storage, and secretion of catecholamine, as well as production of various peptides, neurohormones, and chromaffin protein grains. Paraganglioma is typical in its clinical manifestations, such as paroxysmal or consecutive elevation of blood pressure, headache, dizziness, palpitation, sweating, fainting, and blurred vision. It is also known as catecholamine syndrome. ${ }^{4,6,20,21}$ Located in the vagina, paraganglioma has some special symptoms, such as irregular vaginal bleeding, vaginal pain, or finding a vaginal wall mass during routine gynecological examination. Sometimes, serious cardiovascular complications like hypertension, tachycardia, arrhythmia, or myocardial infarction may arise from the stimulation of surgery or coitus. ${ }^{15,17}$ In this case, the young woman had irregular vaginal bleeding, and suffered from dizziness, headache, and palpitation after physical exercise. Her blood

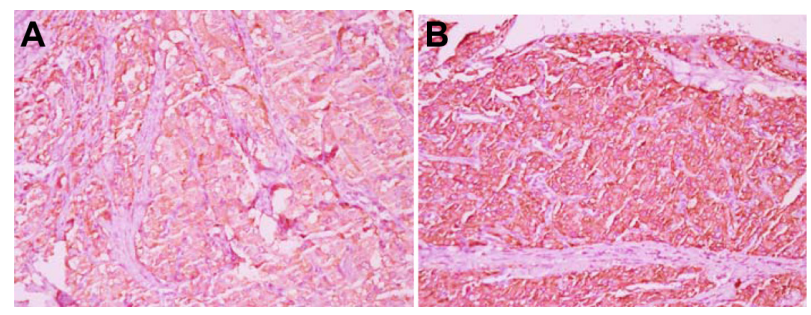

Figure 3 Positive immunohistochemical staining for chromogranin (400x) (A); positive immunohistochemical staining for synaptophysin (400×) (B). 
pressure and heart rate fluctuated abnormally during the biopsy examination, which coincided with functional nonchromaffin paraganglioma.

It is difficult to make a preoperative diagnosis of vaginal paraganglioma due to the lack of specific symptoms, and it may be misdiagnosed as vaginal rhabdomyosarcoma, leiomyoma, or hemangioma, among others. Therefore, it should be definitively diagnosed based only on histological findings. ${ }^{22}$

Ultrasound, CT, or magnetic resonance imaging is useful for delineating the location, while ${ }^{18} \mathrm{~F}-\mathrm{FDG}$-PET helps to estimate malignant, multiple, and metastatic lesions. ${ }^{23,24}$ In this case, the vaginal mass was not found by ultrasound, probably because it was not examined by transvaginal ultrasound, although it unusual hypermetabolism of FDG under PET/CT appeared, which matched with the tumor's features. It has been reported that ${ }^{123}$ I-metaiodobenzylguanidine has strong affinity to chromaffin cell tissues when used as tracer imaging to effectively diagnose or locate paraganglioma. However, this detection technology had not been widely used..$^{25}$ Moreover, an assay of catecholamine and noradrenaline in blood and urine also helped to diagnosis paraganglioma. Patients with functional nonchromaffin paraganglioma may have an increase of catecholamine and noradrenaline in blood and urine, along with blood pressure elevation. ${ }^{26}$ Such information was not available in this case.

Whenever it comes to either functional or nonfunctional vaginal paraganglioma, all the literature suggests that surgical operation currently seems to be the most effective treatment. Because it cannot be completely determined as functional vaginal paraganglioma before operation, the perioperative period is very important. ${ }^{27}$ Usually, an $\alpha$-receptor antagonist is used for catecholamine inhibition. It has been reported that interventional embolization of uterine artery was carried out in one case. ${ }^{18}$ During the operation of the uterine artery, fluctuation of blood pressure, arrhythmia, pneumonedema, myocardial ischemia, or shock may be life-threatening. Those complications can be decreased to $3 \%$ by sufficient preoperative preparation..$^{28}$

It is widely recognized that paraganglioma is a slowly growing tumor, with no or low latent malignancy. However, it cannot be determined just by histological morphology. Instead, it should be judged malignant on the bases of neoplasm recurrence, metastasis of lymph nodes or nonchromaffin tissues, and invasion or infiltration to the adjacent apparatus. ${ }^{29-31}$ Due to the possibility of neoplasm recurrence and metastasis, as reported, patients need periodic checks and long-term follow-up. ${ }^{27,31}$ In this case, the woman had complete resection of the tumor as well as vaginal reconstruction performed. Repeat $\mathrm{CT}$ examination did not reveal any local recurrence or distant metastasis during the 12-month follow-up period. We suggested the patient have a yearly pelvic CT scan and gynecological examination.

\section{Acknowledgment}

This work was supported by Chongqing Medical Scientific Research Projects (grant 2013-2-026).

\section{Disclosure}

The authors report no conflicts of interest in this work.

\section{References}

1. DeLellis RA, Lloyd R, Heitz PU, Eng C. Pathology and Genetics: Tumours of Endocrine Organs. Lyon: IARC; 2004.

2. Renard J, Clerici T, Licker M, Triponez F. Pheochromocytoma and abdominal paraganglioma. J Visc Surg, 2011;148:e409-e416.

3. Kshirsagar AY, Dombate VD, Vinchurkar KM, PareekVA. Retroperitoneal para-aortic paraganglioma. Int Surg. 2005;90:141-143.

4. Erickson D, Kudva YC, Ebersold MJ, et al. Benign paragangliomas: clinical presentation and treatment outcomes in 236 patients. $J$ Clin Endocrinol Metab. 2001;86:5210-5216.

5. Lucon AM, Falci R Jr, Praxedes JN. Multicentric pheochromocytoma and involvement of the inferior vena cava. Sao Paulo Med J. 2001;119: 86-88.

6. Lack EF, Wieneke JA. Paragangliomas. In: Carter D, Greenson JK, Reuter VE, Stoler MH, editors. Sternberg's Diagnostic Surgical Pathology. 3rd ed. Philadelphia: Lippincott Williams \& Wilkins; 1999;2:625-648.

7. Mahdavi A, Silberberg B, Malviya VK, Braunstein AH, Shapiro J. Gangliocytic paraganglioma arising from mature cystic teratoma of the ovary. Gynecol Oncol. 2003;90:482-485.

8. Alamowitch B, Mausset V, Ruiz A, et al. Phéochromocytome non sécrétant du ligament large révélé par une péritonite appendiculaire [Non-secreting pheochromocytoma of the broad ligament revealed by appendicular peritonitis]. Presse Med. 1999;28:225-228. French.

9. Aron DC, Marks WM, Alper PR, Karam JH. Pheochromocytoma of the broad ligament. Localization by computerized tomography and ultrasonography. Arch Intern Med. 1980;140:550-552.

10. Beham A, Schmid C, Fletcher CD, Auböck L, Pickel H. Malignant paraganglioma of the uterus. Virchows Arch A Pathol Anat Histopathol. 1992;420:453-457.

11. Isambert $\mathrm{N}$, Gros $\mathrm{P}$, Commegeille $\mathrm{P}$, et al. Paragangliome malin de l'uterus [Malignant paraganglioma of the uterus]. Ann Med Interne (Paris). 2000;151:311-313. French.

12. Colan TJ, Dardick I, O'Connell G. Paraganglioma of the vulva. Int J Gynecol Pathol. 1991;10:203-208.

13. Young TW, Thrasher TV. Nonchromaffin paraganglioma of the uterus. A case report. Arch Pathol Lab Med. 1982;106:608-609.

14. Chishima F, Tamura M, Nakazawa T, et al. Paraaortic paraganglioma arising in an ovarian carcinoma patient mimicking lymph node metastasis. J Obstet Gynaecol Res. 2010;36:204-208.

15. Hassan A, Bennet A, Bhalla S, et al. Paraganglioma of the vagina: report of a case, including immunohistochemical and ultrastructural findings. Int J Gynecol Pathol. 2003;22:404-406.

16. Parkes SE, Raafat F, Morland BJ. Paraganglioma of the vagina: the first report of a rare tumor in a child. Pediatr Hematol Oncol. 1998;15: 545-551.

17. Shen JG, Chen YX, Xu DY, Feng YF, Tong ZH. Vaginal paraganglioma presenting as a gynecologic mass: case report. Eur J Gynaecol Oncol. 2008;29:184-185. 
18. Akl MN, Naidu SG, McCullough AE, Magtibay PM. Vaginal paraganglioma presenting as a pelvic mass. Surgery. 2010;147: 169-171.

19. Brustmann H. Paraganglioma of the vagina: report of a case. Pathol Res Pract. 2007;203:189-192.

20. Landsberg L, Young JB. Pheochromocytoma. In: Fauci AS, Bratunwald E, Isselbacher KJ, et al, editors. Harrison's Principles of Internal Medicine. 14th ed. New York: Mcgraw-Hill; 1998:2057-2060.

21. Young WF Jr. Paragangliomas: clinical overview. Ann N Y Acad Sci. 2006;1073:21-29.

22. Costantini E, Cochetti G, Porena M. Vaginal para-urethral myxoid leiomyoma: case report and review of the literature. Int Urogynecol J Pelvic Floor Dysfunct. 2008;19:1183-1185.

23. Sahdev A, Sohaib A, Monson JP, Grossman AB, Chew SL, Reznek RH. CT and MR imaging of unusual locations of extra-adrenal paragangliomas (pheochromocytomas). Eur Radiol. 2005;15:85-92.

24. Royo P, de Luis E, Manero MG, Velloso MJ, Toledo G, Alcázar JL. Pelvic paraganglioma. J Ultrasound Med. 2007;26:261-265.

25. Var der Harst E, de Herder WW, Bruining HA, et al. [(123)I] metaiodobenzy and [(11)In] octreotide uptake in benign and malignant pheochromocytomas. J Clin Endocrinol Metab. 2001;86:685-693.
26. Lenders JW, Eisenhofer G, Mannelli M, Pacak K. Phaeochromocytoma. Lancet. 2005;366:665-675.

27. Kazic MR, Zivaljevic VR, Milan ZB, Paunovic IR. Preoperative risk factors, morbidity and outcome of 145 patients during phaeochromocytoma resection. Acta Chir Belg. 2011;111:223-227.

28. Wald O, Shapira OM, Murar A, Izhar U. Paraganglioma of the mediastinum: challenges in diagnosis and surgical management. J Cardiothorac Surg. 2010;5:19.

29. Alvarenga CA, Lopes JM, Vinagre J, et al. Paraganglioma of seminal vesicle and chromophobe renal cell carcinoma: a case report and literature review. Sao Paulo Med J. 2012;130:57-60.

30. Park J, Song C, Park M, et al. Predictive characteristics of malignant pheochremocytoma. Korean J Urol. 2011;52:241-246.

31. Foo SH, Chan SP, Ananda V, Rajasingam V. Dopamine-secreting phaeochromocytomas and paragangliomas: clinical features and management. Singapore Med J. 2010;51:e89-e93.
OncoTargets and Therapy

\section{Publish your work in this journal}

OncoTargets and Therapy is an international, peer-reviewed, open access journal focusing on the pathological basis of all cancers, potential targets for therapy and treatment protocols employed to improve the management of cancer patients. The journal also focuses on the impact of management programs and new therapeutic agents and protocols on

\section{Dovepress}

patient perspectives such as quality of life, adherence and satisfaction. The manuscript management system is completely online and includes a very quick and fair peer-review system, which is all easy to use. Visit http://www.dovepress.com/testimonials.php to read real quotes from published authors. 